\title{
Influência do nitrogênio degradável no rúmen sobre a degradabilidade in situ, os parâmetros ruminais e a eficiência de síntese microbiana em novilhos alimentados com cana-de-açúcar ${ }^{1}$
}

\section{Roselene Nunes da Silveira ${ }^{2}$, Telma Teresinha Berchielli ${ }^{3}$, Roberta Carrilho Canesin 4 , Juliana Duarte Messana ${ }^{4}$, Juliano José de Resende Fernandes ${ }^{5}$, Alexandre Vaz Pires ${ }^{6^{*}}$}

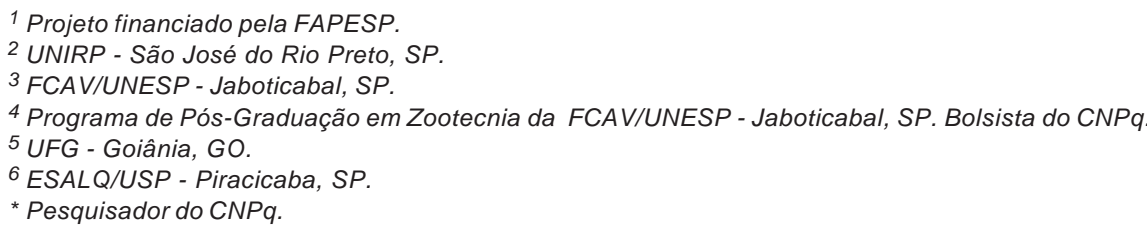

RESUMO - Objetivou-se avaliar o efeito da deficiência de nitrogênio degradável no rúmen (NDR), utilizando como volumoso cana-de-açúcar suplementada com uréia, farelo de soja ou farelo de glúten de milho - 60, sobre a eficiência de síntese microbiana e a degradabilidade in situ da matéria seca (MS) e da fibra em detergente neutro (FDN) em novilhos mestiços. Utilizaram-se oito novilhos canulados no rúmen e duodeno, distribuídos em dois quadrados latinos $4 \times 4$ e alimentados com cana-de-açúcar e cana-de-açúcar suplementada com uréia, farelo de soja ou farelo de glúten de milho-60. $\mathrm{O}$ pH e a concentração de $\mathrm{N}-\mathrm{NH}_{3}$ foram mensurados no fluido ruminal antes e 2, 4, 6 e 8 horas após o fornecimento da ração. Utilizou-se a fibra em detergente ácido indigestível como indicador de fluxo duodenal. A eficiência microbiana foi determinada pelas bases purinas. As fontes de proteína degradável no rúmen não influenciaram a degradabilidade da matéria seca, entretanto, o maior valor de degradabilidade efetiva da FDN foi obtido com a cana-de-açúcar com farelo de soja. O pH e a concentração de $\mathrm{N}-\mathrm{NH}_{3}$ observados com todas as dietas foram adequados para o crescimento dos microrganismos ruminais. A deficiência de nitrogênio degradável no rúmen não influencia a síntese de proteína microbiana e a dinâmica de fase líquida.

Palavras-chave: farelo de soja, glúten de milho-60, nitrogênio amoniacal, purinas, uréia

\section{Ruminal degradable nitrogen for steers fed sugar cane: in situ degradability, ruminal parameters and microbial synthesis efficiency}

\begin{abstract}
The objective of this work was to evaluate the ruminal degradable nitrogen (RDN) deficit using as roughage sugar cane supplemented with urea, soybean meal, or corn gluten meal 60 on the microbial synthesis efficiency, in situ dry matter (DM) and neutral detergent fiber (NDF) degradability. The treatments were: sugar cane, sugar cane with urea, soybean meal or corn gluten meal 60. Eight rumen and duodenum cannulated steers were used and arranged according to two $4 \times 4$ Latin Squares. The $\mathrm{pH}$ and $\mathrm{N}_{-} \mathrm{NH}_{3}$ were determined in the ruminal fluid before and 2, 4, 6 and 8 hours after feeding. The duodenal flow was estimated by indigestible acid detergent fiber. The microbial efficiency was determined by purine. RDN did not affect the DM and the highest effective degradability was observed in sugar cane supplemented with soybean meal in the NDF degradability. The $\mathrm{pH}, \mathrm{N}-\mathrm{NH}_{3}$ values were appropriate to the microbial synthesis in all the evaluated diets. The RDN deficiency did not affect the microbial protein synthesis and the dynamics of the liquid phase.
\end{abstract}

Key Words: ammonia nitrogen, corn gluten meal, purine, soybean meal, urea

\section{Introdução}

Em grande parte do território nacional, os bovinos são alimentados com dietas à base de cana-de-açúcar. O uso racional desta forragem tem várias razões: elevada produção por unidade de área cultivada, cultivo relativamente fácil, baixo custo por unidade de matéria seca produzida; e maior disponibilidade no período de escassez de forragem nos pastos. No entanto, a cana-de-açúcar é um alimento desbalanceado, com baixos teores de proteína e de cálcio e fósforo e elevados teores de açúcares totais e fibra em detergente neutro. 
Estudos comprovam que a digestão da fibra no rúmen pode ser afetada pelo nível de proteína, principalmente em dietas com forragem de baixa qualidade. A proteína é o nutriente de maior custo unitário na alimentação de ruminantes, por isso é fundamental a realização de estudos que possibilitem sua melhor utilização.

Em sistemas de balanceamento de ração, busca-se ajustar tanto a disponibilidade de energia fornecida pelo alimento para os microrganismos ruminais quanto a demanda de amônia e/ou aminoácidos por esses microrganismos. São freqüentes as dúvidas quanto à necessidade, principalmente das bactérias celulolíticas, de nitrogênio para degradação da fibra e para seu máximo crescimento microbiano (Morrison \& Mackie, 1996).

As exigências protéicas do animal são atendidas mediante a absorção intestinal de aminoácidos provenientes da proteína microbiana sintetizada no rúmen e da proteína não-degradada no rúmen (Valadares Filho, 1995). Outro parâmetro para verificar se a dieta fornecida está adequada às características fisiológicas do ruminante é a concentração de nitrogênio amoniacal ( $\left.\mathrm{N}-\mathrm{NH}_{3}\right)$ ruminal. A concentração mínima necessária para manter máxima taxa de crescimento microbiano varia de acordo com a fermentação da dieta. Aumento da concentração ruminal de amônia quando fornecido maior teor de proteína bruta na dieta foi verificado por Rihani et al. (1993), Cruz Soto et al. (1994) e Hennessy et al. (1995).

A manutenção de concentração adequada de nitrogênio amoniacal no rúmen é, portanto, indispensável para o crescimento bacteriano e, nas mais variadas situações, 40 a $100 \%$ do nitrogênio exigido pelos microrganismos poderia ser derivado do nitrogênio amoniacal (Stern \& Hoover, 1979).

$\mathrm{O}$ pH ruminal é uma característica importante associada à degradação da fração fibrosa dos volumosos utilizados na alimentação de ruminantes. Esse parece ser o principal impacto para redução na degradação da fibra (Hoover, 1986), pois, quando o $\mathrm{pH}$ atinge valores de 5,5 ou 5,0, o crescimento dos microrganismos celulolíticos e a digestão da fibra podem ser completamente inibidos. McCollum \& Galyean (1985) observaram que o $\mathrm{pH}$ da digesta ruminal, amostrada em vários horários, não foi influenciado pela suplementação protéico energética e variou de 6,2 a 6,5 quando novilhos foram alimentados com feno de pasto nativo de baixa qualidade.

Este estudo foi realizado com o objetivo de avaliar a eficiência do nitrogênio degradável no rúmen de bovinos alimentados com cana-de-açúcar suplementada com uréia, glúten de milho- 60 ou farelo de soja sobre a degradabilidade in situ da matéria seca e da fibra em detergente neutro, os parâmetros de fermentação ruminal, o pH, a concentração de $\mathrm{N}-\mathrm{NH}_{3}$ e ácidos graxos voláteis, a eficiência de síntese microbiana e a dinâmica da fase líquida.

\section{Material e Métodos}

O experimento foi conduzido no Setor de Avaliação de Alimentos e de Digestibilidade do Departamento de Zootecnia da Faculdade de Ciências Agrárias e Veterinárias, Campus de Jaboticabal/UNESP, São Paulo.

Utilizaram-se oito novilhos mestiços Europeu $\times$ Zebu, canulados no rúmen e no duodeno, com peso vivo médio inicial de $410 \mathrm{~kg}$ e aproximadamente 26 meses de idade. Os animais foram alimentados com cana-de-açúcar suplementada com uréia, glúten de milho - 60 ou farelo de soja. As dietas compostas contendo uréia, glúten de milho-60 ou farelo de soja eram isonitrogenadas e formuladas com base na composição em proteína bruta dos alimentos (Tabela 1), considerando os requisitos de proteína para mantença, de acordo com o AFRC (1993), com base no nitrogênio endógeno basal, que inclui perdas urinárias endógenas e parte do nitrogênio metabólico fecal, além das perdas por descamação de tecidos e pêlos, admitindo-se eficiência de utilização igual a um. Na dieta com cana-de-açúcar + uréia, foi adicionado sulfato de amônio como fonte de enxofre, na proporção de 9:1, e, para suprir o déficit de energia, foi utilizado amido de milho para que todas as dietas fossem isoenergéticas, incluindo a dieta com canade-açúcar na forma exclusiva. A água foi fornecida à vontade e todos os animais receberam aproximadamente 50 g de sal mineral (cálcio máximo, 180 g; iodo, 90 mg; fósforo mínimo, 130 g; magnésio, 2.000 mg; zinco, 5.270 mg; cobalto, $100 \mathrm{mg}$; flúor, $1.300 \mathrm{mg}$; cobre máximo: $1.250 \mathrm{mg}$; veículos q.s.p.: $1.000 \mathrm{~g}$; ferro, 2.200; solubilidade do fósforo em ácido cítrico a 2\% mínimo, 95\%; selênio, 15 $\mathrm{mg}$ ), fornecido juntamente com as rações.

A cana-de-açúcar utilizada foi o cultivar SP 80-339 com 12 meses de rebrota e foi cortada manualmente a cada dois dias e picada mecanicamente no momento do fornecimento aos animais, em partículas de aproximadamente $1,5 \mathrm{~cm}$. No momento em que o alimento era fornecido ao animal, as fontes de nitrogênio foram adicionadas sobre a cana-deaçúcar picada. $\mathrm{O}$ alimento foi fornecido uma vez ao dia, às $7 \mathrm{~h}$, ajustando-se a quantidade de sobras em aproximadamente $10 \%$ do oferecido por animal.

O experimento foi dividido em quatro períodos experimentais de 22 dias: 14 dias para adaptação dos animais às dietas e 8 dias para as coletas de conteúdo ruminal, digesta duodenal e incubação das bolsas de náilon. 
Para o isolamento das bactérias ruminais, foi coletado líquido ruminal 1 hora após a alimentação. Cerca de 3,0 L de digesta sólida e líquida ruminal de cada animal foram coletados e homogeneizados manualmente com 1,0 L de solução salina $1 \mathrm{~N}$. Posteriormente, a mistura foi filtrada em tecido duplo de algodão coletando-se amostras líquidas de aproximadamente 2,0 L, que foram armazenadas e congeladas a $-10^{\circ} \mathrm{C}$. O isolamento das bactérias das amostras de digesta ruminal foi feito por procedimentos de centrifugações diferenciais, conforme metodologia citada por Cecava et al. (1990). Após o isolamento, as amostras foram liofilizadas e submetidas à determinação da composição em matéria seca, matéria mineral e nitrogênio total, conforme descrito por Silva \& Queiroz (2002).

O teor de nitrogênio não-amoniacal (NNA) no duodeno foi obtido pela diferença entre a concentração de N-total e $\mathrm{N}-\mathrm{NH}_{3}$ da digesta duodenal. Para determinação do fluxo duodenal, foram coletadas amostras de digesta duodenal, via cânula, durante quatro dias, três coletas por dia, a intervalos de 8 horas, com intervalo de 6 horas entre os dias, a fim de que, no final de quatro dias, fossem obtidas 12 amostras de digesta duodenal, por animal, conforme metodologia descrita por Calsamiglia et al. (1995). As amostras foram pré-secas em estufa ventilada a $55^{\circ} \mathrm{C}$, por 72 a 96 horas, logo após as coletas, e processadas em moinho com peneira com crivos de $2 \mathrm{~mm}$. Uma amostra composta por animal foi elaborada para determinação das purinas e posterior estimativa do fluxo de nitrogênio microbiano, pela relação $\mathrm{N}$ purinas: $\mathrm{N}$ bacteriano total, conforme procedimento descrito por Zinn \& Owens (1986) com modificações propostas por Ushida et al. (1985).

A degradabilidade in situ foi determinada utilizando-se a técnica da bolsa de náilon. As amostras do bagaço de cana-de-açúcar foram moídas em peneiras com crivos de $5 \mathrm{~mm}$ e colocadas em sacos de náilon $100 \%$ poliamida $(14 \times 7 \mathrm{~cm})$ com porosidade de $50 \mathrm{~mm}$, na quantidade de $5 \mathrm{~g}$, a fim de se manter relação próxima de $20 \mathrm{mg}$ de amostra/ $\mathrm{cm}^{2}$ (Nocek, 1988).

Antes da incubação, as bolsas de náilon foram imersas em água à temperatura ambiente por 1 hora, depois foram colocadas simultaneamente no rúmen e, posteriormente, retiradas em ordem do menor para o maior tempo. Os tempos de incubação utilizados foram 3, 6 12, 24, 48, 72, 96 e 120 horas. Depois de retiradas do rúmen, as bolsas foram imersas imediatamente em água fria e lavadas até a água se tornar translúcida e, posteriormente, foram secas em estufa de ventilação forçada a $55^{\circ} \mathrm{C}$ por 48 horas e pesadas. A fração solúvel foi obtida submergindo duas bolsas de náilon de cada material incubado em água por 1 hora a $38^{\circ} \mathrm{C}$

Tabela 1 - Composição química dos ingredientes e das dietas e ingestão diária de proteína degradável no rúmen

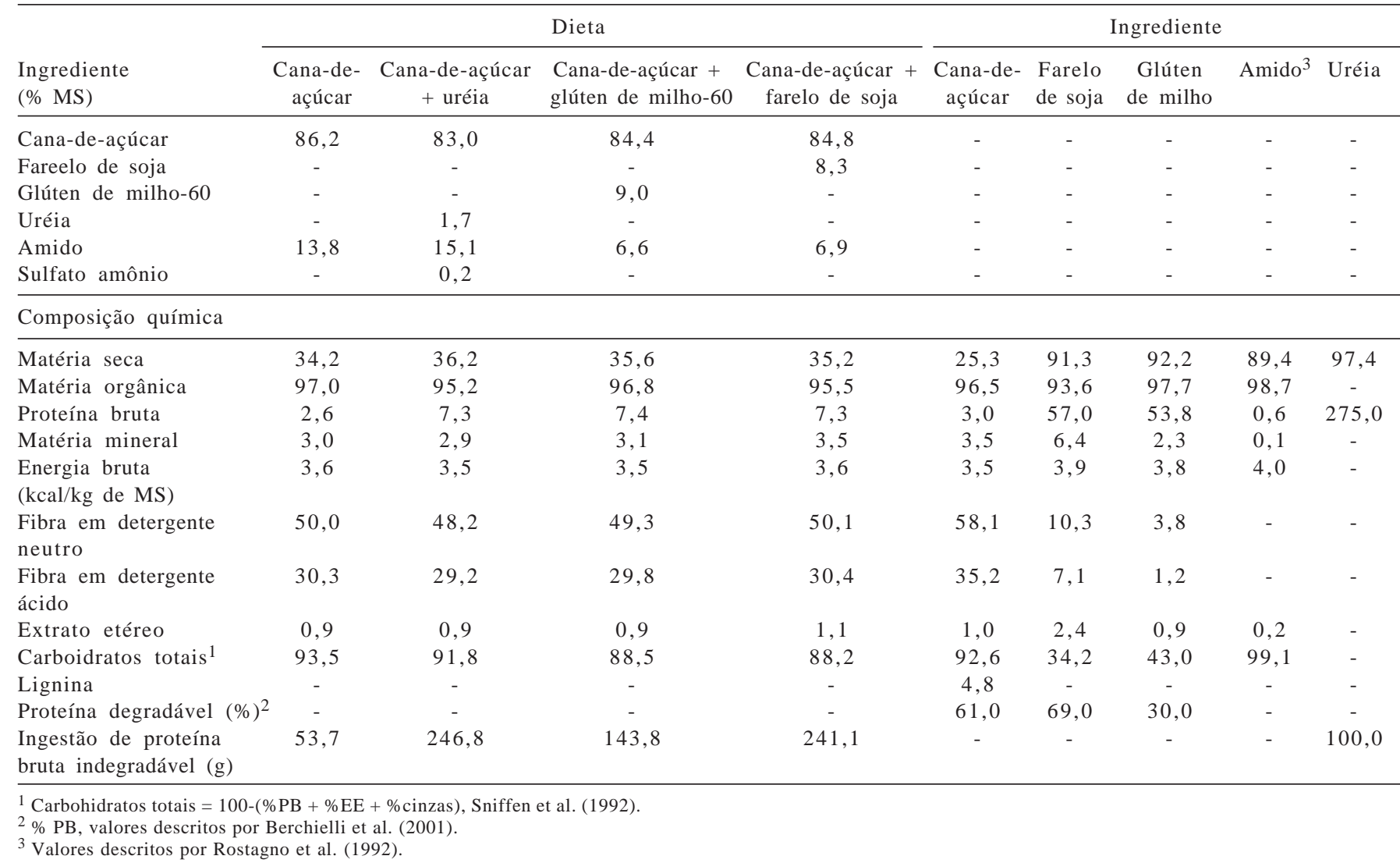


(Porcionato et al., 2004; Silveira et al., 2002), lavadas manualmente e, posteriormente, também foram secas em estufa a $55^{\circ} \mathrm{C}$ por 48 horas. A diferença de peso (antes e após o tratamento) foi considerada fração solúvel "a” do modelo proposto por Ørskov \& McDonald (1979).

As degradabilidades potenciais (DP) foram calculadas segundo o modelo: $\mathrm{DP}=\mathrm{a}+\mathrm{b}\left(1-\mathrm{e}^{-\mathrm{c} . \mathrm{t}}\right)$, para $\mathrm{t}>\mathrm{L}$ proposto por Mehrez \& Ørskov (1977), em que: a = fração imediatamente solúvel; $b$ = fração insolúvel mas potencialmente degradável; c = taxa constante de degradação da fração b; $\mathrm{t}$ = tempo de incubação; e $\mathrm{L}$ = tempo de colonização. As degradabilidades efetivas (DE) foram calculadas pela equação proposta por Ørskov \& McDonald (1979), considerando taxa de passagem de $2 \%$, em que $\mathrm{DE}=\mathrm{a}+\mathrm{b} . \mathrm{c} /(\mathrm{c}+\mathrm{k})$, de modo que a = fração solúvel em água; $b$ = fração insolúvel em água, mas potencialmente degradável; $\mathrm{c}=$ taxa constante de degradação da fração b; e k = taxa de passagem da fração sólida do conteúdo ruminal.

As amostras de líquido ruminal para determinação do $\mathrm{pH}$, de $\mathrm{N}-\mathrm{NH}_{3}$ e dos ácidos graxos voláteis (AGV) foram coletadas antes do fornecimento da dieta (tempo zero) e 2 , 4, 6, e 8 horas após a alimentação.

O marcador utilizado foi o Co-EDTA, segundo Úden et al. (1980), fornecido em dose única de $30 \mathrm{~g}$ por animal diluídos em $300 \mathrm{~mL}$ de água destilada e infundidos pela cânula diretamente no rúmen de cada animal, 1 hora após o fornecimento de alimento. As amostragens de líquido ruminal foram realizadas antes da infusão do marcador e a cada 2 horas até completar 12 horas de administração do marcador.

As determinações dos teores de matéria seca, cinzas, lignina e extrato etéreo das amostras de digesta duodenal e dos componentes da ração foram realizadas conforme metodologias descritas por Silva \& Queiroz (2002); as de fibra em detergente neutro (FDN) e fibra em detergente ácido (FDA), de acordo com Van Soest et al. (1991); as de energia bruta (EB), em bomba calorimétrica; e as de proteína bruta dos alimentos e nitrogênio total das bactérias ruminais e duodenais, pelo método de Dumas em aparelho Leco 528 LC (Etheridge et al., 1998).

A concentração de $\mathrm{N}-\mathrm{NH}_{3}$ foi determinada por destilação com hidróxido de potássio $2 \mathrm{~N}$, conforme metodologia descrita por Fenner (1965), adaptada por Vieira (1980), e a dos AGV foi determinada de acordo com Palmiquist \& Conrad (1971). Os fluxos diários de matéria seca no duodeno foram determinados utilizando-se como indicador interno fibra detergente ácido indigestível (FDAi), obtida pelo método in vitro, após 144 horas de incubação (Berchielli et al., 2000).

$\mathrm{Na}$ análise estatística dos resultados, o delineamento experimental utilizado foi de dois quadrados latinos $4 \times 4$, com quatro animais, quatro tratamentos e quatro períodos experimentais. A análise de variância e a comparação de médias pelo teste Tukey, a 5\% de significância, foram feitas pelo programa SAS (2004) utilizando-se a análise de variância com medidas repetidas no tempo, pelo procedimento MIXED do SAS (2004), para avaliar pH, nitrogênio amoniacal e AGV. As médias foram também submetidas à análise de contrastes ortogonais considerando $5 \%(\mathrm{P}<0,05)$ como nível de significância e até $20 \%$ como tendência $(P<0,20)$.

\section{Resultados e Discussão}

Não houve diferença $(\mathrm{P}>0,05)$ no valor médio obtido com todas as dietas para a fração insolúvel potencialmente degradável (b) $(17,13)$, que foi inferior ao de $31,71 \%$ encontrado por Franzolin \& Franzolin (2000), que avaliaram dietas à base de cana-de-açúcar para bovinos e bubalinos, fornecida à vontade com quantidade diária de $3 \mathrm{~kg} / \mathrm{animal}$ de concentrado contendo $18,7 \%$ de proteína bruta (Tabela 2). As degradabilidades potencial e efetiva da matéria seca foram inferiores (55,40 e 46,98\%) às observadas por Franzolin \& Franzolin (2000), que obtiveram valores de 77,82 e $63,06 \%$. Esses baixos valores de degradabilidade efetiva provavelmente estão associados aos baixos teores de proteína bruta nas dietas, de 2,6\% para cana-de-açúcar; 7,3\% para cana-de-açúcar + uréia; 7,4\% para cana-deaçúcar + glúten de milho; e 7,3\% para cana-de-açúcar + farelo de soja, respectivamente.

A média encontrada neste trabalho para a fração b (74,22\%) foi superior à descrita por Aroeira et al. (1995), que observaram valor de 52,91\% para a fração b quando avaliaram a degradabilidade da fibra em detergente neutro (FDN) em vacas em lactação alimentadas com cana-deaçúcar + uréia. Entretanto, esses autores obtiveram taxa de degradação da fração b $(k d)(4,2 \% / h)$ de 1,95\%/hora e, como conseqüência, encontraram valor superior de degradabilidade efetiva da FDN (70,29\%), o mesmo observado para a degradabilidade efetiva da matéria seca.

Carmo et al. (2001) também encontraram taxas de degradação da fração b superiores, variando de 3,09 a 3,34\%/hora para a matéria seca e de 2,73 a 3,05\%/hora para a FDN. Os baixos valores encontrados neste trabalho provavelmente estão relacionados à baixa demanda de nitrogênio no rúmen e aos baixos valores de degradabilidade efetiva.

A degradabilidade efetiva da FDN da dieta com canade-açúcar + farelo de soja foi elevada (43,21\%) em comparação à daquelas com cana-de-açúcar na forma exclusiva (36,28\%), cana-de-açúcar + uréia (31,08\%) e cana-de-açúcar 
Tabela 2 - Frações solúvel (a), insolúvel potencialmente degradável (b), taxa de degradação da fração b (kd) e degradabilidades potencial (DP) e efetivas (DE) considerando taxa de passagem de $2 \%$ da matéria seca (MS) e da fibra em detergente neutro (FDN)

\begin{tabular}{|c|c|c|c|c|c|}
\hline Dieta & Fração a (\%) & Fração b (\%) & $\begin{array}{c}\text { Degradação } \\
\text { da fração b }(\% / h)\end{array}$ & $\begin{array}{c}\text { Degradabilidade } \\
\text { potencial (\%) }\end{array}$ & $\begin{array}{c}\text { Degradabilidade } \\
\text { efetiva (\%) }\end{array}$ \\
\hline \multicolumn{6}{|c|}{ Matéria seca } \\
\hline Cana-de-açúcar & 38,27 & 17,30 & 1,53 & 55,57 & 45,77 \\
\hline Cana-de-açúcar + uréia & 38,27 & 16,81 & 2,26 & 55,08 & 47,19 \\
\hline Cana-de-açúcar + glúten de milho-60 & 38,27 & 14,83 & 2,77 & 53,10 & 46,88 \\
\hline Cana-de-açúcar + farelo de soja & 38,27 & 19,58 & 2,00 & 57,85 & 48,06 \\
\hline Média & 38,27 & 17,13 & 2,14 & 55,40 & 46,98 \\
\hline \multicolumn{6}{|c|}{ Fibra em detergente neutro } \\
\hline Cana-de-açúcar & - & 72,93 & 1,98 & 71,51 & 36,28 \\
\hline Cana-de-açúcar + uréia & - & 72,52 & 1,50 & 71,86 & 31,26 \\
\hline Cana-de-açúcar + glúten de milho-60 & - & 74,84 & 1,73 & 73,72 & 34,71 \\
\hline Cana-de-açúcar + farelo de soja & - & 76,58 & 2,59 & 75,64 & 43,21 \\
\hline Média & - & 74,22 & 1,95 & 73,18 & 36,37 \\
\hline
\end{tabular}

+ glúten de milho(34,71\%). Esse resultado pode ser atribuído à maior degradação ruminal do farelo de soja, que proporcionou melhor crescimento microbiano e aumento na degradação da fibra.

Houve diferença significativa nos valores de $\mathrm{pH}$ ruminal entre as fontes de proteína degradável no rúmen ( $\mathrm{P}=0,0349)$, os horários de coleta ( $\mathrm{P}<0,0001)$ e interação fontes protéicas $\times$ horário ( $\mathrm{P}=0,0075)$, conforme observado na Figura 1a. Os maiores valores médios de $\mathrm{pH}(7,09)$, para todas as dietas, foram obtidos no tempo zero (antes da alimentação) e os menores $(\mathrm{P}<0,05), 9$ horas após a alimentação $(6,38)$. Os valores médios observados 2, 4 e 6 horas após alimentação foram 6,65; 6,58 e 6,54, respectivamente, e não diferiram entre si $(\mathrm{P}>0,05)$.

$\mathrm{O}$ pH ruminal dos animais alimentados com cana-deaçúcar na forma exclusiva foram superiores aos obtidos com as demais dietas em todos os horários de coleta, o que pode ser atribuído ao fato de a dieta ser composta exclusivamente de volumoso, o que provocou maior mastigação e ruminação pelo animal e, conseqüentemente, maior produção de saliva (Silva et al., 2007).

O valor médio de $\mathrm{pH}$ ruminal foi de 6,87 nos animais alimentados com cana-de-açúcar exclusiva, 6,58 naqueles alimentados com cana-de-açúcar + uréia, 6,58 naqueles alimentados com cana-de-açúcar + glúten de milho-60 e 6,55 naqueles alimentados com cana-de-açúcar + farelo de soja. Apesar da diferença numérica, não houve diferença significativa $(\mathrm{P}>0,05)$ nos valores médios entre as dietas com cana-de-açúcar, cana-de-açúcar + uréia e cana-de-açúcar + glúten de milho, no entanto, os valores obtidos com a dieta com cana-de-açúcar + farelo de soja foram inferiores $(\mathrm{P}=0,044)$ ao encontrado com cana-de-açúcar na forma exclusiva, porém não diferiu dos demais $(P>0,05)$. Esses (a)

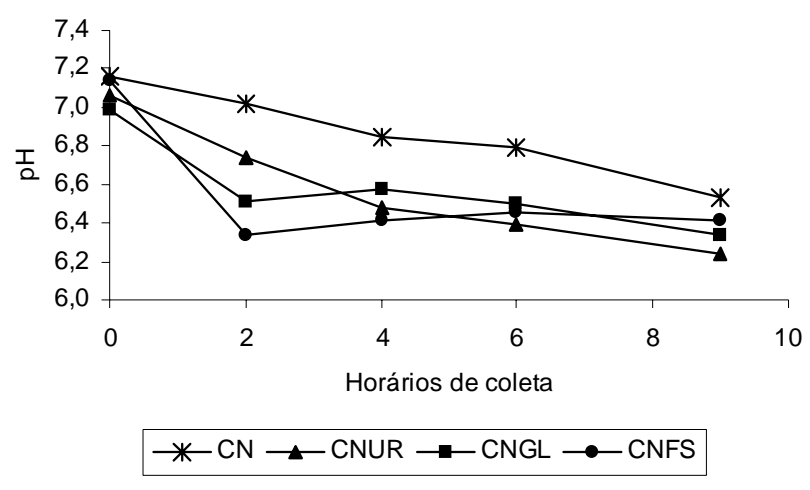

(b)

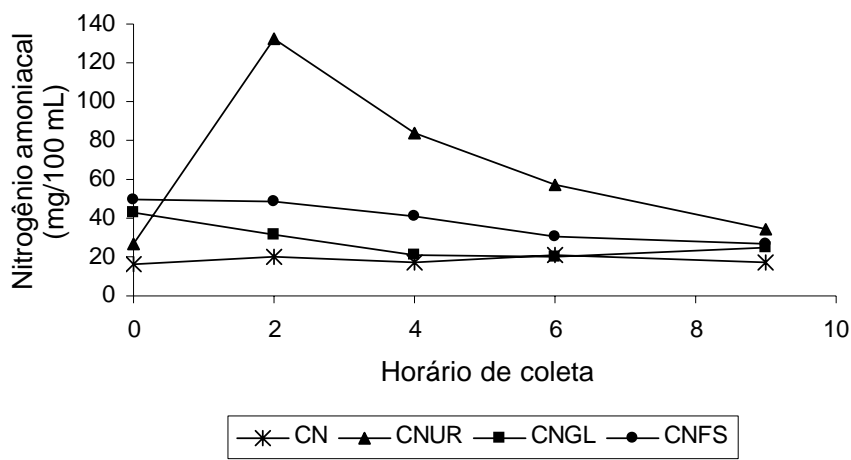

Figura 1 - Valores médios de pH ruminal (a) e nitrogênio amoniacal $\left(\mathrm{N}-\mathrm{NH}_{3}\right)$ ruminal (b) antes (0), 2, 4, 6 e 9 horas após a alimentação dos animais com cana-deaçúcar (CN), cana-de-açúcar + uréia (CNUR), canade-açúcar + glúten de milho-60 (CNGL) e cana-deaçúcar + farelo de soja (CNFS). 
valores foram próximos aos observados por Silva et al. (2007), de 6,0 a 7,0, em bovinos alimentados com feno de capim-tifton 85 suplementado com diferentes fontes de nitrogênio. Segundo esses autores, o ambiente ruminal nos animais mantidos com as dietas com volumoso apresentava condições ideais para a atividade das bactérias celulolíticas (pH de 6,0 a 6,7).

Houve diferença significativa nas concentrações de $\mathrm{N}-\mathrm{NH}_{3}$ ruminal entre as fontes protéicas estudadas $(\mathrm{P}=0,0379)$, os horários de coleta $(\mathrm{P}=0,0006)$ e interação fonte protéica $\times$ horário $(\mathrm{P}<0,001)$. As concentrações médias de $\mathrm{N}-\mathrm{NH}_{3}$ ruminal foram de 18,09; 66,86; 27,90 e $39,24 \mathrm{mg} \mathrm{N}-\mathrm{NH}_{3} / 100 \mathrm{~mL}$ de líquido ruminal, respectivamente, nos animais mantidos com dietas cana-de-açúcar, cana-de-açúcar + uréia, cana-de-açúcar + glúten de milho e cana-de-açúcar + farelo de soja.

Um pico de produção de nitrogênio amoniacal ruminal foi observado 2 horas após a alimentação (Figura 1b) nos animais que receberam cana-de-açúcar com uréia, conforme descrito por Santos (2006). As concentrações de $\mathrm{N}-\mathrm{NH}_{3}$ ruminal foram suficientes para o crescimento bacteriano, conforme o valor mínimo citado por Preston (1986), de $5 \mathrm{mg}$ $\mathrm{N}-\mathrm{NH}_{3} / 100 \mathrm{~mL}$. No entanto, o nível de amônia deve ser superior a $10 \mathrm{mg} / \mathrm{dL}$ para que haja aumento da digestão ruminal da matéria seca e superiores a $20 \mathrm{mg} / \mathrm{dL}$ para que ocorra aumento da ingestão de matéria seca (Leng, 1990).

A concentração $\mathrm{N}-\mathrm{NH}_{3}$ ruminal é conseqüência do equilíbrio entre sua produção, absorção e utilização pelos microrganismos. Bactérias ruminais utilizam $\mathrm{N}-\mathrm{NH}_{3}$ ruminal como fonte de nitrogênio para a síntese de proteína microbiana, mas a fermentação ruminal da proteína freqüentemente produz mais $\mathrm{N}-\mathrm{NH}_{3}$ ruminal que os microrganismos podem utilizar (Preston, 1986). Os dados obtidos entre os animais alimentados com cana-de-açúcar + uréia nos horários de 2 e 4 horas após a alimentação indicam a ocorrência dessa maior produção de $\mathrm{N}-\mathrm{NH}_{3}$ ruminal, pois, apesar do valor médio mais elevado de $\mathrm{N}-\mathrm{NH}_{3}$, a degradabilidade efetiva da matéria seca não foi o maior valor apresentado (Tabela 2).

Existe um sinergismo entre os níveis de acidez $(\mathrm{pH})$ e de $\mathrm{N}-\mathrm{NH}_{3}$ no rúmen; por meio deles, é possível aumentar o crescimento microbiano e a degradação da fibra do alimento, obtendo-se assim maior consumo de alimentos. Na dieta com cana-de-açúcar exclusiva, o valor de $\mathrm{pH}$ foi adequado $(6,87)$, porém os valores de $\mathrm{N}-\mathrm{NH}_{3}$ ruminal foram inferiores $(18,49 \mathrm{mg} / 100 \mathrm{~mL})$ aos obtidos com as demais, o que pode ter ocasionado menor ingestão de matéria seca, $3,29 \mathrm{~kg}$ (Tabela 4). No caso das demais dietas, este sinergismo pode ter ocorrido, pois os valores de $\mathrm{pH}$ e $\mathrm{N}-\mathrm{NH}_{3}$ ruminais estão dentro do esperado e o consumo de matéria seca (Tabela 4) foi próximo em todas as dietas: cana-de-açúcar + uréia (4,58 kg de MS), cana-de-açúcar + glúten de milho (4,76 kg de MS) e cana-deaçúcar + farelo de soja (4,97 kg de MS). Desta forma, observou-se considerável aumento no consumo - 27\% para a dieta com cana-de-açúcar + uréia, 32,6\% para a dieta com cana-de-açúcar + glúten de milho e 38,4\% para a dieta com cana-de-açúcar + farelo de soja - em relação à cana-de-açúcar fornecida na forma exclusiva.

As concentrações de acetato e propionato e as relações acetato:propionato, butirato e ácidos graxos voláteis totais (Tabela 3) não diferiram $(\mathrm{P}>0,05)$ entre as fontes protéicas estudadas, logo as fontes protéicas não influenciaram esses resultados. As proporções entre os ácidos graxos voláteis no rúmen mantiveram-se estáveis em todas as dietas, com valores médios de 67:26:7 para acetato:propionato:butirato, respectivamente. Segundo

Tabela 3 - Concentração média de ácidos graxos voláteis (mmol/mL), relação acetato propionato e ácidos graxos totais em bovinos alimentados com rações à base de cana-de-açúcar

\begin{tabular}{|c|c|c|c|c|c|}
\hline \multirow[t]{2}{*}{ Parâmetro } & \multicolumn{4}{|c|}{ Dieta } & \multirow[b]{2}{*}{$\mathrm{CV}$} \\
\hline & $\begin{array}{l}\text { Cana-de- } \\
\text { açúcar }\end{array}$ & $\begin{array}{c}\text { Cana-de-açúcar } \\
+ \text { uréia }\end{array}$ & $\begin{array}{l}\text { Cana-de-açúcar } \\
+ \text { glúten de milho-60 }\end{array}$ & $\begin{array}{l}\text { Cana-de-açúcar } \\
+ \text { farelo de soja }\end{array}$ & \\
\hline \multicolumn{6}{|c|}{ Ácidos graxos voláteis $(\mathrm{mmol} / \mathrm{mL})$} \\
\hline Acetato & 99,74 & 100,04 & 99,83 & 99,96 & 5,63 \\
\hline Propionato & 38,11 & 38,47 & 37,96 & 38,44 & 0,20 \\
\hline Butirato & 10,44 & 9,99 & 10,30 & 10,61 & 0,96 \\
\hline Acetato:Propionato & 2,62 & 2,60 & 2,63 & 2,60 & 0,55 \\
\hline AGV ruminal total & 147,29 & 148,41 & 148,08 & 149,10 & 0,82 \\
\hline \multicolumn{6}{|c|}{$\% \mathrm{AGV}$} \\
\hline Acetato & 67,72 & 67,15 & 67,30 & 67,28 & - \\
\hline Propionato & 25,87 & 25,72 & 25,66 & 25,85 & - \\
\hline Butirato & 6,81 & 7,14 & 7,04 & 6,87 & - \\
\hline
\end{tabular}

$\mathrm{CV}=$ coeficiente de variação 
Nussio et al. (2006), dietas à base de volumoso apresentam proporções geralmente próximas de 65:25:10 de acetato:propionato:butirato.

As ingestões de matéria seca e nitrogênio e o fluxo de matéria orgânica no duodeno diferiram $(\mathrm{P}<0,5)$ entre as dietas e foram maiores quando fornecidas as dietas com as fontes protéicas em estudo, em comparação à cana-deaçúcar fornecida na forma exclusiva. A deficiência de proteína degradável no rúmen teve efeito $(\mathrm{P}<0,05)$ sobre a quantidade de matéria seca e nitrogênio ingerido e os fluxos de matéria orgânica para o duodeno.

Não foi observada diferença nos níveis de ingestão de nitrogênio pelos animais entre as dietas suplementadas, considerando que as rações eram isoprotéicas. As análises de contraste revelaram $(\mathrm{P}<0,20)$ aumento do fluxo de $\mathrm{N}$-total (g/dia) e do NNA à adição das fontes de proteína nãodegradável no rúmen. O maior fluxo de N-total obtido com a dieta com cana-de-açúcar + glúten de milho (55,73 g/dia) pode estar relacionado ao fato de o glúten de milho-60 ser uma fonte de nitrogênio de baixa degradabilidade no rúmen, o que aumenta o fluxo de nitrogênio para o duodeno. Os resultados de fluxos de N-total e nitrogênio não-amoniacal para o duodeno confirmam que as dietas com proteína de baixa e média degradabilidade ruminal (com glúten de milho e farelo de soja) contribuíram com maior fluxo de $\mathrm{N}$-total e nitrogênio não-amoniacal para o duodeno em relação à dieta com uréia.

Apesar do baixo valor de proteína bruta oferecida aos animais alimentados exclusivamente com cana-de-açúcar, o fluxo de $\mathrm{N}$-microbiano para o duodeno (em \% do N-total) foi semelhante ao observado com o fornecimento de cana-deaçúcar + uréia, 87,59 e 87,58\% do N-total, respectivamente.
A eficiência de síntese de proteína microbiana não diferiu entre as dietas (Tabela 5), mas diminuiu, pela análise de contrastes, quando expressa em g N/Mcal de EDR na dieta com cana-de-açúcar + farelo de soja em comparação às dietas com uréia ou glúten de milho-60, fato confirmado pelo sinergismo entre o açúcar da cana e o nitrogênio da uréia, potencializando a utilização desses pelas bactérias ruminais, e o glúten de milho-60 (que possui proteína de baixa degradação) com a degradação da celulose da cana-deaçúcar, ocasionando aumento no crescimento microbiano.

Os valores médios encontrados para matéria orgânica aparentemente digerida no rúmen, em g N/kg, $(18,95)$ estão acima dos encontrados por Rocha (2001), de 14,7 g N/kg. No entanto, os valores de energia digestível no rúmen, g N/Mcal de EDR, foram muito inferiores $(0,63)$ ao obtido por Rocha (2001), de 3,64.

O valor médio de 17,93 g N/kg de carboidratos totais disponíveis digeridos no rúmen também foi inferior aos encontrados por Rocha (2001) e Silveira et al. (2002), de 19,97 e 19,01 g N/kg, respectivamente.

A deficiência de proteína degradável no rúmen não causou diferença significativa em nenhum dos parâmetros estudados ( $\mathrm{P}>0,05)$ (Tabela 6).

O volume ruminal médio obtido foi de $63,84 \mathrm{~L}$, o que corresponde a $15,57 \%$ do peso vivo, próximo aos valores preconizados por Owens \& Goestch (1988) como ideais, de 15 a $21 \%$ do peso do animal, e do encontrado por Silva et al. (2007), de 14,58\% do peso do animal.

Houve relação inversa entre a taxa de diluição e seu tempo de reciclagem. A dieta com farelo de glúten de milho-60 tendeu a proporcionar maior taxa de diluição e menor tempo de reciclagem dos fluidos ruminais. O mesmo foi

Tabela 4 - Ingestão de matéria seca e nitrogênio, fluxos de matéria orgânica, nitrogênio microbiano e nitrogênio não-amoniacal no duodeno em bovinos alimentados com rações à base de cana-de-açúcar

\begin{tabular}{|c|c|c|c|c|c|c|c|c|}
\hline \multirow[t]{2}{*}{ Parâmetro } & \multicolumn{4}{|c|}{ Dieta } & \multirow[b]{2}{*}{ CV } & \multicolumn{3}{|c|}{ Contraste } \\
\hline & $\begin{array}{l}\text { Cana-de- } \\
\text { açúcar }\end{array}$ & $\begin{array}{l}\text { Cana-de- } \\
\text { açúcar + uréia }\end{array}$ & $\begin{array}{l}\text { Cana-de- } \\
\text { açúcar + glúten } \\
\text { de milho-60 }\end{array}$ & $\begin{array}{l}\text { Cana-de- } \\
\text { açúcar + farelo } \\
\text { de soja }\end{array}$ & & $\begin{array}{l}\mathrm{CN} \times \mathrm{CNUR}, \\
\mathrm{CNGL}, \mathrm{CNFS}\end{array}$ & $\begin{array}{c}\text { CNFS } \times \\
\text { CNGL, CNUR }\end{array}$ & $\begin{array}{c}\text { CNGL } \times \\
\text { CNUR }\end{array}$ \\
\hline & \multicolumn{4}{|c|}{ Consumo } & & \multicolumn{3}{|c|}{ Probabilidade } \\
\hline Matéria seca kg/dia) & $3,29 B$ & $4,58 \mathrm{~A}$ & $4,76 \mathrm{~A}$ & $4,97 \mathrm{~A}$ & 14,48 & $<0,01$ & 0,29 & 0,59 \\
\hline \multirow[t]{2}{*}{ Nitrogênio (g/dia) } & $9,03 \mathrm{~B}$ & $50,45 \mathrm{~A}$ & $51,69 \mathrm{~A}$ & $50,45 \mathrm{~A}$ & 29,73 & $<0,01$ & $<0,01$ & $<0,01$ \\
\hline & \multicolumn{5}{|c|}{ Fluxo para o duodeno } & & & \\
\hline Matéria orgânica (kg/dia) & $1,24 \mathrm{~B}$ & $1,62 \mathrm{~A}$ & $1,80 \mathrm{~A}$ & $1,76 \mathrm{~A}$ & 13,45 & $<0,01$ & 0,30 & 0,68 \\
\hline Nitrogênio total (g/dia) & 29,65 & 33,81 & 55,73 & 42,38 & 46,98 & 0,09 & 0,07 & 0,17 \\
\hline $\begin{array}{l}\text { Nitrogênio microbiano } \\
(\% \mathrm{~N} \text { total) }\end{array}$ & 87,59 & 87,58 & 69,59 & 62,95 & 44,56 & 0,77 & 0,09 & 0,17 \\
\hline $\begin{array}{l}\text { Nitrogênio não-amoniacal } \\
\text { (g/dia) }\end{array}$ & 29,50 & 33,60 & 55,60 & 42,19 & 45,26 & 0,07 & 0,07 & 0,16 \\
\hline $\mathrm{pH}$ duodeno & 2,75 & 2,64 & 2,78 & 2,62 & - & - & - & - \\
\hline
\end{tabular}

CN = cana-de-açúcar, CNUR = cana-de-açúcar + uréia, CNFS = cana-de-açúcar + farelo de soja; CNGL = cana-de-açúcar + glúten de milho-60; CV = coeficiente de variação Valores seguidos da mesma letra na linha não diferem $(\mathrm{P}>0,05)$ entre si pelo teste Tukey. 
Tabela 5 - Ingestões médias da matéria orgânica aparentemente digerida no rúmen (MOADR), de carboidratos totais disponíveis digeridos no rúmen (CTDR) e de energia digestível no rúmen (EDR) e eficiência de síntese microbiana desses nutrientes ingeridos



CV: coeficiente de variação. Valores seguidos da mesma letra não diferem entre si $(\mathrm{P}>0,05)$ pelo teste Tukey.

CN = cana-de-açúcar, CNUR = cana-de-açúcar + uréia; CNGL = cana-de-açúcar + glúten de milho-60; CNFS = cana-de-açúcar + farelo de soja .

Tabela 6 - Volume, taxa de diluição, tempo de reciclagem e taxas de reciclagem e de fluxo ruminal das dietas experimentais

\begin{tabular}{|c|c|c|c|c|c|c|}
\hline Parâmetro & \multicolumn{4}{|c|}{ Dieta } & Média & $\begin{array}{l}\text { Digestibilidade da } \\
\text { matéria seca }\end{array}$ \\
\hline Taxa de diluição (\%/h) & 6,48 & 7,45 & 7,97 & 6,06 & 6,99 & 6,48 \\
\hline Tempo de reciclagem (horas) & 21,28 & 16,72 & 14,29 & 12,56 & 16,21 & 12,01 \\
\hline Taxa de reciclagem (vezes/dia) & 1,56 & 1,45 & 1,79 & 1,91 & 1,68 & 1,56 \\
\hline
\end{tabular}

observado por Silva et al. (2007) utilizando as mesmas fontes protéicas com feno de capim-tifton 85 como volumoso de baixa degradação ruminal.

O tempo médio de reciclagem, de 16,21 horas, foi similar aos encontrados por Bürger et al. (2000), de 15,05 horas, e de Silva et al. (2007), 17,35 horas. O valor médio de taxa de reciclagem (vezes/dia) foi de 1,68 neste trabalho, valor próximo aos de 1,56 e 1,5 encontrados por Silva et al. (2007) e Silveira et al. (2002).

O volume de líquido que deixou o rúmen por hora (taxa de fluxo) foi de 4,25 L, superior ao obtido por Berchielli et al. (1996), 2,0 L, e Bürger et al. (2000), 2,3 L, enquanto Silveira et al. (2002) encontraram valor médio de 4,38 L.

Os animais mantidos com a dieta contendo cana-deaçúcar + farelo de soja apresentaram maior valor numérico de volume ruminal (73,76L). No entanto, apresentaram menor taxa de diluição (6,06\%/hora), contrariando os dados obtidos por Berchielli et al. (1996) e Pereira et al. (2002), mas confirmando os encontrados por Bürger et al. (2000), Martins et al. (2006) e Silva et al. (2007).

De acordo com Evans (1981), a taxa de reciclagem aumenta com os níveis de ingestão, o que provavelmente está associado a um decréscimo no tempo de retenção das partículas no rúmen. As estimativas obtidas neste trabalho são condizentes com essa informação, pois as ingestões foram de 3,29; 4,58; 4,76 e 4,97 kg de MS para dietas cana-de-açúcar, cana-de-açúcar + uréia, cana-de-açúcar + glúten de milho e cana-de-açúcar + farelo de soja, respectivamente (Tabela 4).

\section{Conclusões}

As fontes de nitrogênio degradável, uréia, glúten de milho e farelo de soja, não influenciam a degradabilidade in situ da matéria seca da cana-de-açúcar e a síntese de proteína microbiana. A adição de uréia e glúten de milho-60 reduz a degradabilidade in situ da fibra em detergente neutro em comparação à cana-de-açúcar fornecida exclusivamente. As fontes de nitrogênio influenciam os valores de pH e $\mathrm{N}-\mathrm{NH}_{3}$.

\section{Literatura Citada}

AGRICULTURAL AND FOOD RESEARCH COUNCIL - AFRC. Energy and protein requirements of ruminants. Wallingford: $C A B$ International, 1993. 159p.

AROEIRA, L.J.M.; LOPES, F.C.F.; DAYRELL, M.S. et al. Digestibilidade, degradabilidade e taxa de passagem da cana-deaçúcar mais uréia e do farelo de algodão em vacas mestiças 
holandês x zebu em lactação. Revista Brasileira de Zootecnia, v.24, n.6, p.1016-1026, 1995.

BERCHIELLI, T.T.; ANDRADE, P.; FURLAN, C.L. Avaliação de indicadores internos em ensaios de digestibilidade. Revista Brasileira de Zootecnia, v.29, n.3, p.830-833, 2000.

BERCHIELLI, T.T.; RODRIGUEZ, N.M.; GONÇALVES, L.C. Polietilenoglicol e cobalto-EDTA como marcadores da fase líquida ruminal. Arquivo Brasileiro de Medicina Veterinária e Zootecnia, v.48, n.4, p.463-471, 1996.

BERCHIELli, T.T.; BISCEGLI, T.L.; MARTINS, A.S. et al. Avaliação da degradabilidade da matéria seca e fibra em detergente neutro da silagem de milho com diferentes fontes de proteína. In: REUNIÓN DE LA ASSOCIACIÓN LATINOAMERICANA DE PRODUCCIÓN ANIMAL, 37. 2001, Habana. Anais... Havana: Associación Latinoamericana de Producción Animal, 2001. v.9, p.2401-2404.

BÜRGER, P.J.; PEREIRA, J.C.; COELHO DA SILVA, J.F. et al. Taxas de passagem e cinética da degradação ruminal em bezerros holandeses alimentados com dietas contendo diferentes níveis de concentrado. Revista Brasileira de Zootecnia, v.29, n.1, p.225-235, 2000.

CALSAMIGLIA, S.; CAJA, G.; STERN, M.D. et al. Effects of ruminal versus duodenal dosing of fish meal on ruminal fermentation and milk composition. Journal of Dairy Science, v.78, n.9, p.1999-2007, 1995.

CARMO, C.A; BERCHIELLI, T.T.; ANDRADE, P. et al. Degradabilidade da matéria seca e fibra em detergente neutro da cana-de-açúcar (Saccharum spp) com diferentes fontes de proteína. Revista Brasileira de Zootecnia, v.30, n.6, p.2126-2133, 2001.

CECAVA, M.J.; MERCHEN, N.R.; BERGER, L.L. et al. Intestinal supply of amino acids in sheep fed alkaline hydrogen peroxide-treated wheat straw-based diets supplemented with soybean meal or combinations of corn gluten meal and blood meal. Journal of Animal Science, v.68, n.2, p.467-477, 1990.

CRUZ SOTO, R.; MUHAMMED, S.A.; NEWBOLD, C.J. et al. Influence of peptides, amino acids and urea on microbial activity in the rumen of sheep receiving grass hay and on growth of rumen bacteria in vitro. Animal Feed Science and Technology, v.49, n.1-2, p.151-161, 1994.

ETHERIDGE, R.D.; PESTI G.M.; FOSTER, E.H. A comparison of nitrogen values obtained utilizing the Kjeldahl nitrogen and Dumas combustion methodologies (Leco CNS 2000) on samples typical of an animal nutrition analytical laboratory. Animal Feed Science and Technology, v.60, n.73, p.21-28, 1998.

EVANS, E. An evaluation of the relationships between dietary parameters and rumen liquid turnover rate. Canadian Journal of Animal Science, v.61, n.1, p.91-96, 1981.

FRANZOLIN, R.; FRANZOLIN, M.H.T. População protozoários ciliados e degradabilidade ruminal em búfalos e bovinos zebuínos sob dieta à base de cana-de-açúcar. Revista Brasileira de Zootecnia, v.29, n.6, p.1853-1861, 2000.

HENNESSY, D.W.; KOHGUN, P.J.; WILLIAMSON, P.J. et al. The effect of nitrogen and protein supplementation on feed intake, growth and digestive function of steers with different Bos indicus, Bos taurus genotypes when fed a low quality grass hay. Australian Journal of Agricultural Science, v.46, n.6, p.1121-1136, 1995.

HOOVER, W.H. Chemical factors involved in ruminal fiber digestion. Journal of Dairy Science, v.69, p.2755-2766, 1986.

LENG, R.A. Factors affecting the utilization of "poor-quality" forages by ruminants particularly under tropical conditions. Nutrition Research and Review, v.3, p.277-303, 1990.

MARTINS, A.S.; VIEIRA, P.F.; BERCHIELLI, T.T. et al. Taxa de passagem e parâmetros ruminais em bovinos suplementados com enzimas fibrolíticas. Revista Brasileira de Zootecnia, v.35, n.3, p.1186-1193, 2006.
McCOLLUM, F.T.; GALYEAN, M.L. Influence of cottonseed meal supplementation on voluntary intake, rumen fermentation and rate of prairie hay in beef steers. Journal of Animal Science, v.60, n.2, p.570, 1985.

MEHREZ, A.Z.; ØRSKOV, E.R. A study of the artificial fibre bag techinique for determining the digestiblity of feeds in the rumem. Journal of Agricultural Science, v.88, n.3, p.645-650, 1977.

MORRINSON, M.; MACKIE, R.I. Nitrogen metabolism by ruminal microorganisms: current understanding and future perspectives. Australian Journal of Agricultural Research, v.47, n.2, p.227-246, 1996.

NOCECK, J.E. In situ and other methods to estimate ruminal protein and energy digestibility: a review. Journal of Dairy Science, v.71, n.5, p.2051-2069, 1988.

NUSSIO, L.G.; CAMPOS, F.P.; LIMA, M.L.M. Metabolismo de carboidratos estruturais. In: BERCHIELLI, T.T.; PIRES, A.V.; OLIVEIRA, S.G. (Eds). Nutrição de ruminantes. 1.ed. Jaboticabal: Funep, 2006. p.183-228.

ØRSKOV, E.R.; McDONALD, I. The estimation of protein degradability in the rumen from incubation measurements of feed in weighted according rate passage. Journal of Agricultural Science, v.92, n.2, p.499-503, 1979.

OWENS, F.N.; GOETSCH, A.L. Ruminal fermentation. In: CHURCH, D.C. (Ed.) The ruminant animal digestive physiology and nutrition. Englewood Cliffs: O \& Books Inc., 1988, p.146-171.

PALMIQUIST, D.L.; CONRAD, H. Origin of plasma fatty acids in lactating cows fed high fat diets. Journal of Dairy science, v.54, n.3, p.1025-1033, 1971.

PEREIRA, J.C.; ALMEIDA, M.S.; CECON, P.R. et al. Dinâmica da degradação ruminal por novilhos mantidos em pastagem natural em diferentes épocas do ano. Revista Brasileira de Zootecnia, v.31, n.2, p.740-748, 2002.

PORCIONATO, M.A.F.; BERCHIELLI, T.T.; FRANCO, G.L. et al. Digestibilidade, degradabilidade e concentração amoniacal no rúmen de bovinos alimentados com polpa cítrica peletizada normal ou queimada. Revista Brasileira de Zootecnia, v.33, n.1, p.258-266, 2004.

PRESTON, T.R. Analytical methods for characterizing In: Feed resources for ruminants. Better utilization of crop residues and by products in animal feeding: research guidelines. 2. A practical manual for research workers. Rome: FAO, 1986. p.106.

RIHANI, N.; GARRET, W.N.; ZINN, R.A. Influence of level of urea and method of supplementation on characteristics of digestion of high-fiber diets by sheep. Journal of Animal Science, v.71, n.6, p.1657-1665, 1993.

ROCHA, L.B. Influência da degradabilidade ruminal de diferentes suplementos protéicos na síntese de proteína microbiana em bovinos alimentados com silagem de milho. 2001. 25f. Monografia (Graduação em Zootecnia) Faculdade de Ciências Agrárias e Veterinárias, Universidade Estadual Paulista, Jaboticabal, 2001.

ROSTAGNO, H.S.; SILVA, D.J.; COSTA, P.M.A. et al. Composição de alimentos e exigências nutricionais de aves e suínos. Viçosa, MG: Imprensa Universitária, 1992. 60p.

SANTOS, F.A.P. Metabolismo de proteínas. In: BERCHIELLI, T.T.; PIRES, A.V.; OLIVEIRA, S.G. (Eds). Nutrição de ruminantes. 1.ed. Jaboticabal: Funep, 2006. p.255-286.

STATISTICAL ANALYSIS SYSTEM - SAS. SAS system: SAS/STAT. version 9.0 (software), Cary: SAS Institute, 2004. (CD-ROM).

SILVA, E.A.; BERCHIELLI, T.T.; REIS, R.A. et al. Teores de proteína bruta para bovinos alimentados com feno de capimtifton 85: parâmetros ruminais, eficiência de síntese microbiana e degradabilidade in situ. Revista Brasileira de Zootecnia, v.36, n.1, p.225-237, 2007.

SILVA, D.J.; QUEIROZ, A.C. Análise de alimentos (Métodos químicos e biológicos). 3.ed. Viçosa, MG: Universidade Federal de Viçosa, 2002. 235p. 
SILVEIRA, R.N.; BERCHIELLI, T.T.; FREITAS, D. et al. Fermentação e degradabilidade ruminal em bovinos alimentados com resíduos de mandioca e cana-de-açúcar ensilados com polpa cítrica peletizada. Revista Brasileira de Zootecnia, v.31, n.2, p.793-801, 2002.

SNIFFEN, C.J.; O'CONNOR, J.D.; Van SOEST, P.J. et al. A net carbohydrate and protein system for evaluation cattle diets. II. Carbohydrate and protein availability. Journal of Animal Science, v.70, n.11, p.3562-3577, 1992.

STERN, M.D.; HOOVER, W.H. Methods for determining and factors affecting rumen microbial protein syntheses: a review. Journal of Animal Science, v.49, n.5, p.1590-1603, 1979.

ÚDEN, P.; COLLUCCI, P.E.; Van SOEST, P.J. Investigation of chromium, cerium and cobalt as marker in digesta. Rate of passage studies. Journal Science and Food Agriculture, v.31, n.7, p.625-632, 1980.

USHIDA, K.; LASSALAS, B.; JOUANY, J.P. Determination of assay parameters for RNA analysis in bacterial and duodenal samples by spectrophotometry. Influence of sample treatment and preservation. Reproduction, Nutrition and Development, v.25, n.6, p.1037-1046, 1985.

VALADARES FILHO, S.C. Eficiência de síntese de proteína microbiana, degradação ruminal e digestibilidade intestinal de proteína bruta, em bovinos. In: SIMPÓSIO INTERNACIONAL SOBRE EXIGËNCIAS NUTRICIONAIS DE RUMINANTES, 1995, Viçosa, MG. Anais... Viçosa, MG: JARD, 1995. p.355-388.

Van SOEST, P.J.; ROBERTSON, J.B.; LEWIS, B.A. Methods for dietary fiber, neutral detergent fiber, and nonstarch polysaccharides in relation to animal nutrition. Journal of Dairy Science, v.74, p.3583, 1991.

VIEIRA, P.F. Efeito do formaldeído na proteção de proteínas e lipídeos em rações. 1980. 98f. Tese (Doutorado em Zootecnia) - Universidade Federal de Viçosa, Viçosa, MG, 1980.

ZINN, R.A.; OWENS, F.N. A rapid procedure for purine measurement and its use for estimating net ruminal protein synthesis. Canadian Journal of Animal Science, v.66, n.1, p.157-166, 1986 